\title{
Transplant Depth Influences Tomato Yield and Maturity
}

\author{
Charles S. Vavrina \\ University of Florida, Southwest Florida Research and Education Center, \\ P.O. Drawer 5127, Immokalee, FL 33934
}

Stephen M. Olson

University of Florida, North Florida Research and Education Center, Route

3, Box 4370, Quincy, FL 32351-9529

Phyllis R. Gilreath

Manatee County Extension, 1303 17th Street, Palmetto, FL 34221-2998

Mary L. Lamberts

Dade County Extension, 18710 SW 288 Street, Homestead, FL 33030-2309

Additional index words. stand establishment, early maturity, seedlings

Abstract. 'Agriset', 'All Star', and 'Colonial' tomato (Lycopersicon esculentum Mill.) transplants set to a depth of the first true leaf and 'Cobia' transplants set to a depth of the cotyledon leaves yielded more fruit at first harvest than plants set to the top of the rootball (root-shoot interface). The increase in fruit count was predominantly in the extra-large category. More red fruit at first harvest suggested that deeper planting hastens tomato maturity. The impact of planting depth diminished with successive harvests, indicating the response to be primarily a first-harvest phenomenon in tomato.

Past studies have shown that transplanting depth may influence yield of vegetable crops. Miller et al. (1969) noted that deeper planting of cabbage (Brassica oleracea L. Capitata Group) transplants increased yield and head size. Vavrina et al. (1994) determined that planting bell pepper (Capsicum annuum L.) transplants to the first true leaf increased yield, while having little or no effect on average fruit weight. In the pepper research, the gains in early yield were particularly significant, and it was suggested that deeper planting depth could be affecting plant maturity. However, a literature search did not reveal other cases of transplant depth effects on early development in vegetable crops. Factors other than transplant depth may contribute to maturity. For example, Tewolde et al. (1994) showed that $\mathrm{N}$ deficiency can promote early maturity in Pima cotton (Gossypium barbadense L.). In other crops, improved $\mathrm{P}$ nutrition (Brown et al., 1994) and certain agrochemicals (Vavrina et al., 1995; York, 1983) have promoted or delayed plant maturity.

In this paper, we report on the effects of transplant depth on fresh-market tomato yield and size. Specific attention also was given to effects of transplanting depth on maturity.

Received for publication 20 July 1995 . Accepted for publication 17 Nov. 1995. Florida Agricultural Expt. Station Journal Series no. R-04608. The use of brand names does not constitute a recommendation by the Univ. of Florida to the exclusion of other products. The cost of publishing this paper was defrayed in part by the payment of page charges. Under postal regulations, this paper therefore must be hereby marked advertisement solely to indicate this fact.

\section{Materials and Methods}

Our studies were conducted at four locations in Florida: Homestead $\left(25^{\circ} 30^{\prime} \mathrm{N}\right.$, $\left.80^{\circ} 39^{\prime} \mathrm{E}\right)$, Immokalee $\left(26^{\circ} 27^{\prime} \mathrm{N}, 81^{\circ} 29^{\prime} \mathrm{E}\right)$, Parrish $\left(27^{\circ} 42^{\prime} \mathrm{N}, 82^{\circ} 35^{\prime} \mathrm{E}\right)$, and Quincy $\left(30^{\circ} 42^{\prime} \mathrm{N}, 8^{\circ} 18^{\prime} \mathrm{E}\right)$. The Immokalee and Quincy trials were conducted at Univ. of Florida Research and Education Centers (REC), while those in Parrish and Homestead were conducted in growers' fields.

Tomato transplants were grown commercially in various cell sizes (Johnson Plants, Immokalee, Fla. - bullet style $=26 \mathrm{~cm}^{3}$; Collier Gro, Immokalee, Fla.- - inverted pyramid $=25$ $\mathrm{cm}^{3}$; La Belle Plant World, La Belle, Fla.pointed rectangle $=28 \mathrm{~cm}^{3}$; and Speedling, Sun City, Fla.-inverted pyramid $=25 \mathrm{~cm}^{3}$ ) for three test sites and at the North Florida REC (inverted pyramid $=25 \mathrm{~cm}^{3}$ ) for the Quincy site (Table 1). Although commercial transplant production practices varied somewhat, generalized procedures for all transplant production closely approximated those outlined by Vavrina (1995a). Plants were grown under natural light with seasonal temperatures. The transplants varied in height from season to season due to differences in plant house practices.

Four fresh-market tomato cultivars were used: 'Agriset 761', 'All Star', 'Colonial' (Petoseed, Saticoy, Cailf.), and 'Cobia' (Rogers Seed Co., Boise, Idaho). Cultivars were chosen by regional preference and availability at the plant production facilities.

All field sites used plastic-mulched beds, although planting date, plant spacing, harvest date, irrigation, and fertilizer practices varied (Table 1). The studies spanned the Florida production season, with trials conducted in the fall (1993, 1994), winter (1994), and spring (1994).

Planting depth was determined by morpho-logic position on the plant: to the rootball (RB-just covering the root-shoot interface with soil), the cotyledon leaves (CL), or the first true leaf (FTL) (Vavrina et al., 1994). Three harvests were performed at each site. Fruit from each harvest were separated into red (where applicable) and green categories. Fruit was sorted further into medium ( $>5.7$ to $6.4 \mathrm{~cm})$, large $(>6.4$ to $7.0 \mathrm{~cm})$, and extra-large $(>7.0 \mathrm{~cm})$ diameter categories, according to Florida Tomato Committee specifications for ethylene-gassed green tomatoes (Hochmuth, 1988).

All sites used a randomized complete-block design with six replications, except Quincy, which had four replications. Due to differing site factors, site results were tested separately by analysis of variance with mean separations by Fisher's least significant difference (SAS, 1987).

\section{Results and Discussion}

Total yield at first harvest, as determined by harvestable fruit count per plant, was significantly increased in four of the seven trials by setting tomato transplants to the FTL rather than to the RB depth (Table 2). In the four trials that produced significant differences, yields at first harvest increased by $25 \%$ to $30 \%$. Planting to CL resulted in significantly higher total first-harvest yield than the RB depth in the Homestead trial only, but differences approached statistical significance $(P \leq 0.05)$ in Immokalee in Fall 1993 and in Parrish in Fall 1994. An error in grower harvesting procedure resulted in the loss of three replications at the Parrish site in Spring 1994. The data from this site and the other nonsignificant trials $(P \geq$ 0.05 ) still tended to support the hypothesis that deeper transplanting produces higher early yields.

A consequence of deeper planting appeared to be an increase in the number of extra-large fruit at first harvest (Table 2). In five of the seven trials, significantly more extra-large fruit were produced by planting tomatoes to FTL than to RB. In two of the trials, planting to CL also produced significantly more extra-large fruit than the RB depth.

The impact of planting depth diminished with successive harvests (Table 2). In only one trial did an increase in planting depth influence total yield (Immokalee, Fall 1993) or total extra-large fruit production (Quincy, Spring 1994) after three harvests. In both cases, planting to the FTL was required to achieve such yields. These results may be explained by the yield potential of the hybrid tomato. Whereas the positive effect of planting depth is dramatic at first harvest, the total season yield potential of the hybrid tomato moderates this effect in later harvests to result in equal yields, regardless of planting depth.

The major impact of planting depth was seen at first harvest, suggesting that increasing planting depth may improve early seedling establishment and growth, thereby influenc- 
Table 1. Cultural practices for tomato transplant depth trials in Florida.

\begin{tabular}{|c|c|c|c|c|c|c|c|c|}
\hline $\begin{array}{l}\text { Cultivar, } \\
\text { season, and } \\
\text { site }\end{array}$ & $\begin{array}{c}\text { Transplant } \\
\text { date }\end{array}$ & $\begin{array}{l}\text { In-row } \\
\text { spacing } \\
(\mathrm{cm})\end{array}$ & $\begin{array}{c}\text { Plants/ } \\
\text { plot }\end{array}$ & Replications & Irrigation & $\begin{array}{c}\text { N-P-K } \\
\left(\mathrm{kg} \cdot \mathrm{ha}^{-1}\right)\end{array}$ & $\begin{array}{c}\text { Plant } \\
\text { source }\end{array}$ & $\begin{array}{c}\text { Harvest } \\
\text { dates }\end{array}$ \\
\hline All Star, Fall 1993, Immokalee & 30 Sept. 1993 & 46 & 10 & 6 & Semiclosed & $182-112-296$ & LaBelle Plant World & $\begin{array}{l}21 \text { Dec. } \\
28 \text { Dec. } \\
11 \text { Jan. }\end{array}$ \\
\hline Agriset, Spring 1994, Parrish & 23 Feb. 1994 & 76 & 10 & 3 & Semiclosed & $250-200-500$ & Speedling & $\begin{array}{l}18 \text { May } \\
31 \text { May } \\
13 \text { June }\end{array}$ \\
\hline Colonial, Spring 1994, Quincy & 18 Mar. 1994 & 51 & 12 & 4 & Drip & $182-25-151$ & NFREC $^{z}$ & $\begin{array}{l}2 \text { June } \\
13 \text { June } \\
28 \text { June }\end{array}$ \\
\hline Agriset, Fall 1994, Immokalee & 2 Sept. 1994 & 46 & 10 & 6 & Semiclosed & $182-112-296$ & Johnson Plants & $\begin{array}{l}21 \text { Nov. } \\
29 \text { Nov. } \\
12 \text { Dec. }\end{array}$ \\
\hline Agriset, Fall 1994, Parrish & 31 Aug. 1994 & 76 & 10 & 6 & Seep & $260-170-533$ & Speedling & $\begin{array}{l}16 \text { Nov. } \\
28 \text { Nov. } \\
12 \text { Dec. }\end{array}$ \\
\hline Cobia, Winter 1994, Immokalee & 27 Oct. 1994 & 46 & 10 & 6 & Semiclosed & $182-112-296$ & Collier Gro & $\begin{array}{l}18 \text { Jan. } \\
1 \text { Feb. } \\
10 \text { Feb. }\end{array}$ \\
\hline Cobia, Winter 1994, Homestead & 26 Oct. 1994 & 51 & 12 & 6 & Drip & $180-240-412$ & Collier Gro & $\begin{array}{l}19 \text { Jan. } \\
9 \text { Feb. } \\
22 \text { Feb. }\end{array}$ \\
\hline
\end{tabular}

${ }^{2}$ North Florida Research and Education Center.

Table 2. Yields for fresh-market tomatoes transplanted to three planting depths in seven Florida field studies.

\begin{tabular}{|c|c|c|c|c|}
\hline \multirow[b]{3}{*}{ Depth } & \multicolumn{4}{|c|}{ Fruit/plant } \\
\hline & \multicolumn{2}{|c|}{ First harvest } & \multicolumn{2}{|c|}{ Combined yield } \\
\hline & Total & Extra large & Total & Extra large \\
\hline \multicolumn{5}{|c|}{ Immokalee, Fall 1993} \\
\hline Rootball & 6.0 & 4.5 & 23.5 & 14.0 \\
\hline Cotyledon & 7.2 & 5.2 & 25.9 & 14.7 \\
\hline First true leaf & 8.2 & 5.9 & 27.7 & 16.3 \\
\hline F significance & $*$ & $* *$ & $*$ & NS \\
\hline $\mathrm{LSD}_{0.05}$ & 1.4 & 0.8 & 3.2 & --- \\
\hline \multicolumn{5}{|c|}{ Parrish, Spring 1994z } \\
\hline Rootball & 30.6 & 20.1 & 49.8 & 30.6 \\
\hline Cotyledon & 35.0 & 22.1 & 50.9 & 31.4 \\
\hline First true leaf & 34.7 & 25.4 & 52.6 & 37.3 \\
\hline F significance & NS & NS & NS & NS \\
\hline \multicolumn{5}{|c|}{ Quincy, Spring 1994} \\
\hline Rootball & $12.5^{y}$ & 7.3 & 42.8 & 17.9 \\
\hline Cotyledon & 16.1 & 8.8 & 40.4 & 16.4 \\
\hline First true leaf & 18.0 & 11.8 & 42.0 & 20.8 \\
\hline F significance & NS & $* *$ & NS & $* *$ \\
\hline $\mathrm{LSD}_{0.05}$ & --- & 1.9 & --- & 2.3 \\
\hline \multicolumn{5}{|c|}{ Immokalee, Fall 1994} \\
\hline Rootball & 8.0 & 7.3 & 30.9 & 19.3 \\
\hline Cotyledon & 8.8 & 8.3 & 30.4 & 19.7 \\
\hline First true leaf & 11.2 & 10.0 & 32.0 & 21.1 \\
\hline F significance & * & $*$ & NS & NS \\
\hline $\mathrm{LSD}_{0.05}$ & 2.4 & 1.8 & --- & --- \\
\hline \multicolumn{5}{|c|}{ Parrish, Fall 1994} \\
\hline Rootball & 7.7 & 5.9 & 34.3 & 12.5 \\
\hline Cotyledon & 9.9 & 8.2 & 35.9 & 14.8 \\
\hline First true leaf & 11.0 & 9.3 & 38.7 & 15.9 \\
\hline F significance & $*$ & $*$ & NS & NS \\
\hline $\mathrm{LSD}_{0.05}$ & 2.4 & 2.5 & --- & --- \\
\hline \multicolumn{5}{|c|}{ Immokalee, Winter 1994} \\
\hline Rootball & 2.8 & 2.6 & 18.0 & 10.4 \\
\hline Cotyledon & 2.5 & 2.3 & 19.1 & 10.5 \\
\hline First true leaf & 2.9 & 2.5 & 19.3 & 10.5 \\
\hline F significance & NS & NS & NS & NS \\
\hline \multicolumn{5}{|c|}{ Homestead, Winter 1994} \\
\hline Rootball & 4.7 & 3.5 & 19.8 & 10.3 \\
\hline Cotyledon & 5.5 & 4.2 & 20.1 & 11.2 \\
\hline First true leaf & 5.1 & 4.1 & 19.6 & 11.2 \\
\hline F significance & * & $*$ & NS & NS \\
\hline $\mathrm{LSD}_{0.05}$ & 0.6 & 0.5 & --- & --- \\
\hline
\end{tabular}

${ }^{2}$ Data derived from three replications only (harvester error).

${ }^{y}$ Early data represents first two harvests. Four harvests comprise combined yield as opposed to three in all other trials.

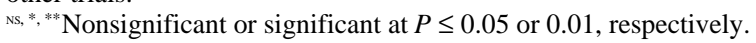

ing plant development. Furthermore, an increase in tomato fruit size, especially in the crown set, may be an indicator of more functional leaf area (Vavrina, 1995b), which could contribute to more rapid maturation.

Natural tomato coloration may be a better estimator of fruit maturity. Therefore, to determine if planting depth was influencing fruit maturity, three trials in which tomatoes had visibly started to redden were examined (Table 3). Planting tomato transplants to the FTL clearly yielded more red fruit at first harvest than planting to the RB in two of three trials. This result also points to a planting depth effect on fruit maturation.

Findings of increased early yield and larger size in tomato fruit with increasing planting depth are consistent with the data found for cabbage (Miller et al., 1969) and pepper (Vavrina etal., 1994). The transplanting depthfruit maturity factor had been intimated in the work with pepper. Data from our research provide support for that premise. Although factors such as plant nutrition and agrochemicals also influence crop maturity (Brown et al., 1994; Tewolde et al., 1994; Vavrina et al., 1995; York, 1983), we believe our results support using increased transplant depth to hasten crop maturation.

In the research with pepper (Vavrina et al., 1994), yield increases attributed to deeper transplanting were hypothesized to result from soil temperature amelioration, enhanced fertilizer and water acquisition, and reduced mechanical displacement shock. These factors, if valid, may apply to tomato as well. Additionally, the greater adventitious root proliferation in tomato compared to pepper (C.S.V., unpublished) suggests the involvement of root-produced hormones.

Deeper transplanting increased early yield, fruit size, or both in all four tomato cultivars tested for most growing seasons and locations. Transplanting to CL increased yield significantly only with 'Cobia', but the trends toward higher yields and increased fruit size were 


\section{Crop Production}

Table 3. Yields of first-harvest red fruit of tomatoes transplanted at three planting depths.

\begin{tabular}{lccc}
\hline & \multicolumn{3}{c}{ No./plant } \\
\cline { 2 - 4 } Depth & Parrish, Fla., Spring 1994z & Immokalee, Fla., Fall 1994 & Parrish, Fla., Fall 1994 \\
\hline Rootball & 5.3 & 2.2 & 1.4 \\
Cotyledon & 8.7 & 2.8 & 2.3 \\
First true leaf & 8.4 & 3.6 & 3.6 \\
F significance & NS & $* *$ & $*$ \\
LSD $_{0.05}$ & --- & 0.7 & 1.4 \\
\hline
\end{tabular}

${ }^{2}$ Three replications only.

ws, **** Nonsignificant or significant at $P \leq 0.05$ or 0.01 , respectively.

evident in most trials. We recommend that fresh-market tomato growers use deeper transplanting techniques as a means to increase early yields and to speed maturation, especially in tropical and semi-tropical climates. Experimenting with this technique at other latitudes should be considered based on similar findings by Miller et al. (1969) with cabbage in North Carolina and the general advice for deeper transplanting provided by New England gardeners (e.g., Crockett, 1977-tomato; Watson, 1865-pepper, cabbage, and other stem-forming plants).
The effect of cultural practices on the suitability of cabbage for once-overharvest. J. Amer. Soc. Hort. Sci. 94:67-69.

SAS Institute. 1987. SAS/STAT software. Version 6.04. SAS Institute, Cary, N.C.

Tewolde, H., C.J. Fernandez, and D.C. Foss. 1994. Maturity and lint of nitrogen- and phosphorus-deficient Pima cotton. Agron. J. 86:303-309.

Vavrina, C.S. 1995a. An introduction to the production of containerized vegetable transplants. Univ. of Florida Coop. Ext. Serv. Bul. 302.

Vavrina, C.S. 1995b. Tomato transplanting reaches new depths. Amer. Veg. Grower 43:16-17.

Brown, J.E., J.M. Dangler, C.H. Gilliam, D.W. Porch, and R.L. Shumack. 1994. Comparison of broiler litter and inorganic nitrogen, phosphorus, and potassium for double-cropped sweet corn and broccoli. J. Plant Nutr. 17:859867.

Crockett, J.U. 1977. Crockett's victory garden. Little, Brown, \& Co., Boston.

Hochmuth, G.J. (ed.). 1988. Tomato production guide for Florida. Univ. of Florida Coop. Ext. Serv. Circ. 98C.

Miller, C.H., W.E. Splinter, and F.S. Wright. 1969.
Vavrina, C.S., K.D. Shuler, and P. R. Gilreath. 1994. Evaluating the impact of transplanting depth on bell pepper growth and yield. HortScience 29:1133-1135.

Vavrina, C.S., P.A. Stansly, and T.X. Liu. 1995. and toxicity to silverleaf whitefly. HortScience 30:1406-1409.

Watson, A. 1865. The American home garden. Harper \& Bros. Publ., Franklin Square, N.Y.

York, A.C. 1983. Cotton cultivar response to mepiquat chloride. Agron. J. 75:663-667. Household detergent on tomato: Phytotoxicity 